\title{
Military technology and sample selection bias
}

\author{
JOHAN FOURIE \\ MARTINE MARIOTTI \\ KRIS INWOOD
}

\section{Stellenbosch Economic Working Papers: WP03/2018}

www.ekon.sun.ac.za/wpapers/2018/wp032018

February 2018

KEYWORDS: height, stature, sample selection bias, convenience samples, World War I, Anglo-Boer War, military strategy

JEL: C8, N3, N4

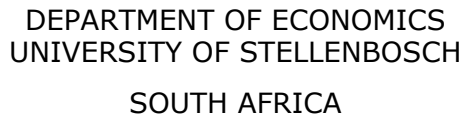

A WORKING PAPER OF THE DEPARTMENT OF ECONOMICS AND THE BUREAU FOR ECONOMIC RESEARCH AT THE UNIVERSITY OF STELLENBOSCH 
While it is well known that labour market fluctuations may affect the supply of labour into particular activities such as crime and military service, other sources of selection bias may be sufficiently powerful to confound hypothesis testing. Selection into military populations, for example, may reflect influences on the demand as well as supply of labour. We argue that changing military technology in the early twentieth century shifted the demand for men of different stature and robustness. Soldiers in the First World War (1914-1918) were shorter on average than those in the AngloBoer War (1899-1902) for reasons that had nothing to do with standard of living or business cycle influences on the labour market. Rather, we argue, the mechanization and bureaucratization of warfare increased the relative value of shorter people permitting a decline in the average height of soldiers. Thus, technological change over the period of these two wars affected labour demand in a way that largely explains an apparent fall in heights.

JEL CODES: C8, N3, N4

KEYWORDS: height, stature, sample selection bias, convenience samples, World War I, AngloBoer War, military strategy 
Many explanations have been put forward for the 'industrial growth puzzle', a phenomenon in which early industrialization appears to undermine child health and adult stature. Reasons include changes in income distribution or variability, an increase in the relative price of nutritious foods, and deteriorating early life health due to urbanization and concomitant increase in disease exposure, longer work hours or diminished breast-feeding (Haines, 2004; Komlos, 1998; Steckel 1995). Others argue that the evidence is flawed because of selection biases in the source documentation: the heights captured by military attestation forms. Shorter men, the argument goes, were selected for military service when tight labour markets reduced the availability of taller men (Bodenhorn, Guinnane and Mroz 2017; Zimran 2018). On this view, macroeconomic fluctuations altered the terms on which labour was supplied to the military and systematically biased the evidence about stature. In this paper we argue that military evidence is vulnerable to another source of selection bias: changes in military preference for men of different height due to evolving military strategy and/or technology.

We investigate this possibility using a large, new dataset of heights of military recruits and policemen, which show that soldiers in the Anglo-Boer War (1899-1902) were taller than those in the First World War (1914-1918). We consider only recruits into British forces in the two wars who were born in England between 1860 and 1890. We further control for observable characteristics such as year of birth, social class and religion and find a significant difference between the heights.

What could explain this apparent difference in military heights in the 14-year period from the beginning of the Anglo-Boer War to the end of the First World War? We posit that new technologies, and the changes in military strategy entailed by those technologies, explain the difference. The Anglo-Boer War, also termed 'the last gentleman's war', was the last war to use cavalry lancers, a military strategy where height is a particular advantage. In contrast, the mechanization of weapons during WW1 meant that soldiers' heights were no longer so important. In this case, improvements to military technology help to explain the apparent decline in stature between the two wars.

Two early twentieth-century wars

The Anglo-Boer War (1899-1902) and the First World War (1914-1918) were two of the largest wars ever fought by Britain. The Anglo-Boer War, or Second South African War, between the Boers of the Transvaal Republic (or the South African Republic) and the Orange Free State on the one side and the United Kingdom with its two South African colonies - the Cape Colony and Natal - on the other, began on 11 October 1899 and lasted until 31 May 1902. Close to 450000 British regulars and colonial forces fought in South Africa against the estimated 88000 Boer and volunteer forces. While the Boers initially made decisive inroads, driving back the British forces to the Natal coast and deep into the Cape Colony, fresh British arrivals and poor military tactics by Boer generals meant that, within a year of the commencement of war, the British had captured the capitals of the two republics, Bloemfontein and Pretoria. The War looked like ending rapidly. Yet it would last for another two years. Boer soldiers, moving in mobile commandos, resorted to guerrilla tactics, strategically attacking British outposts and intercepting deliveries over the vast Highveld terrain. The British responded by instituting concentration camps for Boer women and children, sending captured Boer soldiers to prisoner-of-war camps and implementing scorched earth tactics on the abandoned farms. The War finally ended in May 1902 when the Treaty of Vereeniging was signed.

The Anglo-Boer War was the single most costly colonial war for Britain in the nineteenth century, in terms of both mortality rates and financial costs. An estimated 22000 British and 7000 Boer soldiers died. An additional 27000 Boer men, women and children died in the concentration camps, and many thousands of black South Africans, who fought on both sides of the war, also 
died, although these estimates are less precise. It was not only people that suffered. According to Swart, 326073 horses, $67 \%$ of the total, died between the start and the end of the war. This was because 'both sides relied heavily on mounted troops' (Swart, 2010: 349).

The cavalry was thus largely responsible for the defeat of the Boer forces in early 1900 . Soon after capturing Pretoria, Lord Roberts, just before handing over command of the army to Lord Kitchener in December 1900, established the South African Constabulary (SAC), a volunteer force of armed and mounted police for the new British territories of the Transvaal and Orange River Colony (Grundlingh, 1991; Fourie et al 2017). The plan was to provide stability in the former republics, not only between the Boers and the British but also between the white farmers and the black tribes that still inhabited large parts of the territory. As the war continued, however, the SAC were often involved in skirmishes. In our sample of 8873 individuals who enlisted, of whom 1526 enlisted more than once, 20 were killed in battle.

Figure 1 shows the two British colonies, the Cape Colony and Natal, and the two Boer republics, the Orange Free State and the South African Republic. The towns where at least 100 SAC recruits were discharged indicate the concentration of the Constabulary in the central and eastern Transvaal.

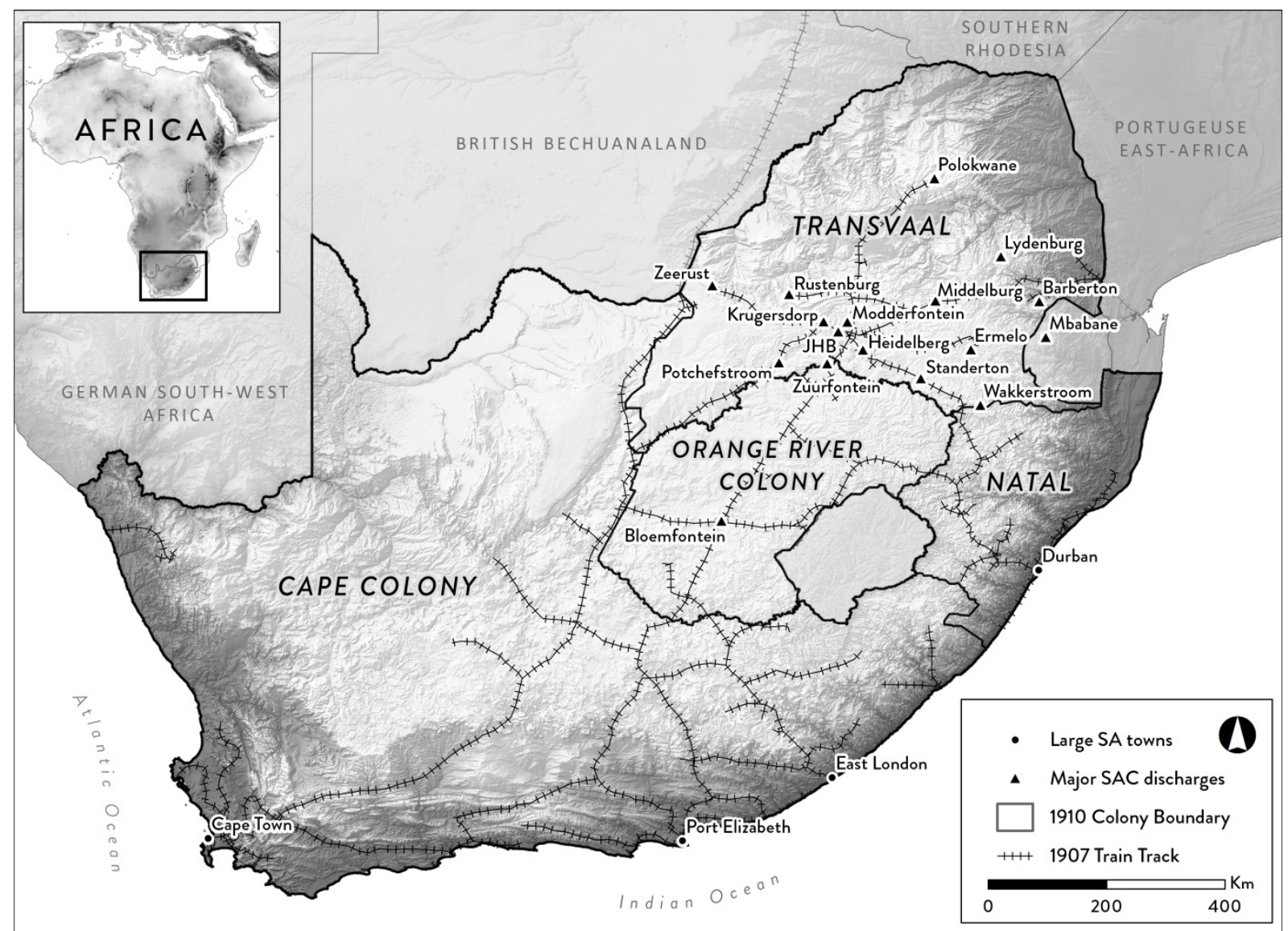

We use the attestation forms of the SAC for three reasons. First, large numbers of English-born recruits enrolled (57\% of the total sample). Second, while attestation forms for more formal regiments were recorded, these often do not specify the exact height of the recruit but only whether he was above the required minimum. Third, military regiments would have had specific duties assigned to each unit. Mounted units, for example, had the specific expectation that recruits must be able to ride a horse. As far as we can determine, this was not the case for the SAC.

We also have access to the records of English-born soldiers who enlisted for service in the AngloBoer War in Australia, Canada and New Zealand. We compare the English-born recruits into the 
Anglo-Boer War to English-born recruits enlisted in the First World War. The war between the Allied powers of France, the United Kingdom and Russia, and the Central powers of Germany and Austria-Hungary began on 28 July 1914 and ended 11 November 1918. An estimated 9 million combatants and 7 million civilians died in what was known as the Great War.

The reason for the high death rates was the use of advanced mechanized technologies. In contrast to earlier wars, the artillery were responsible for the largest number of casualties (Raudzens, 1990: 421). Technological developments during the late nineteenth century allowed new forms of warfare: as Castaldi et al. (2009) note, it was only during WWI that the three key mechanical constituents of the tank - bulletproof armour, internal combustion engine and caterpillar tracks - became available. The new technologies, which included trenches, air reconnaissance, machine guns and barbed wire, required less human muscle than the cavalry arme blanche that had been employed only 14 years earlier. The soldier's height became less important. The technological changes between the Anglo-Boer War and WW1 are likely to have changed the selection criteria for the military.

To test this, we compare English-born soldiers in the two wars. Here we rely on the South African Constabulary described above and data collected and used in previous studies. World War One personnel records supply information about the Australian Imperial Force (Cranfield and Inwood 2015), the Canadian Expeditionary Force (Clarke et al. 2014), the South African Expeditionary Force (Inwood and Masakure 2013) and the WWI British army (Bailey, Hatton and Inwood 2016). The heights of the WWI forces recruited in Australia, Canada and South Africa but born in England are compared to those of the English-born component in the SAC and in the Australian and Canadian troops sent to the Anglo-Boer War (used here for the first time). Our hypothesis is that, because of the technology used in the Anglo-Boer War, height would have been important for selection into the military, whereas for WW1, selection on height would have been less important given the new military strategies.

The horse versus the machine

Why did taller soldiers enlist in the Anglo-Boer War? We argue that differences in military strategy dictated by new technologies offer a novel explanation. During the early phase of the Boer War, the British still used the cavalry lance, a weapon used throughout Europe since the middle ages. However, the success of the lance in the Boer War was limited, with the notable exception of Elandslaagte, where a charging British force caught the retreating Boers and inflicted heavy damages (Badsey, 2007: 87).

The role of the horse in combat was changing; even before the Boer war was over, the cavalry's performance had drawn substantial criticism (Phillips, 2007: 38). Not only was it shifting from an instrument of combat to logistical aid but, where cavalry remained, firearms were beginning to replace the classic blade weaponry. The Boer tactics of trench warfare, their use of artillery and, most importantly, their long-range rifles made the cavalry lance obsolete, and obliged cavalry units to became mounted infantry, dismounting to fight on foot.

Mounted units, though, remained central to the British strategy throughout the war for two reasons: the vast open geography of the Highveld together with the guerrilla tactics of the Boer soldiers during the second half of the war meant that mobility was essential. Citino (2002) notes this in examining the lessons from the War:

The British certainly did come to understand the importance of mobility in the course of the war. The British force in South Africa changed dramatically during the war, from a predominantly infantry force, to a mix of infantry and cavalry units, to an army of mounted infantry. Mobility increased accordingly. 
The need to use cavalry and to recruit soldiers fit for horse-riding was thus paramount. Although the SAC we use in the above empirical analysis were not necessarily recruited for the purposes of battle, they were nevertheless expected to be able to ride a horse; $93 \%$ of the English-born recruits in the SAC reported that they could do so in their attestation forms. ${ }^{1}$ The Anglo-Boer War was the last in which the cavalry charge and the lancer were used en masse. Swart notes that the "horses in this war were among the last to engage in war the way it had been fought for more than 2000 years' (Swart, 2010: 349).

In contrast, WW1 was a mechanized war, especially from 1915 onwards. As one French general remarked after the Battle of Verdun in 1916, 'Three men and a machine gun can stop a battalion of heroes' (Boot, 2006: 167). 'Industrial weaponry', writes Boot (2006: 198), made WWI 'paradoxically both shorter and far more catastrophic than previous "world wars" such as the Seven Years' War or the French Revolutionary and Napoleonic Wars'. Mechanized or industrial warfare was not necessarily the strategy of choice at the start of the war; several cavalry regiments served during the first years of the war. But on the Western Front in the close quarters of trench warfare, their obsolescence was soon apparent. The British had realized this even before the war began. Badsey (2007: 76) notes that:

In a wider military history context, the main impact of the Boer War was that it fostered a number of British military reforms made before the First World War of 1914-1918. Of these, one was that by 1908, alone among the major powers of Europe, the British Empire had the only cavalry entirely armed with an infantry rifle rather than the shorter carbine...

But even mounted infantry rifles would be ineffective against the industrial weapons introduced during the course of the war, such as trench warfare with barbed wire and machine guns. Better artillery and entrenched machine guns made crossing open ground extremely dangerous. By 1916, military technology evolved further to produce the tank which was 'used to crush barbed wire and eliminate machine guns' (Liaropoulos, 2006: 377). Aircraft became essential in collecting information that could give armies a tactical advantage. Large numbers of horses were still used, of course, but increasingly restricted to transportation behind the lines. More importantly for our argument, the relative importance of horses and machinery was changing.

It is, or should be, evident that these new technologies required less human power than the cavalry charges of the Anglo-Boer War. This, we posit, was the reason why so few short men enlisted in the SAC. Cavalry regiments, notably lancers, were selected on unobservable factors correlated with height, such as strength. WWI soldiers, especially from 1915 onwards, had less need of physical strength. In fact, the industrial weapons such as tanks, aircraft and trench warfare may have even benefited shorter individuals.

\section{Modelling the impact of a change in technology}

In modelling the shift in the preference for height we consider a military type of production function where we assume that victory in battle in the late nineteenth and early twentieth century required soldiers, weapons and horses. We do not for the moment consider transport to and from the battlefield.

The production function we use is based on the specification in Krusell, Ohanian, Rios-Rull and Violante (2000) which neatly allows us to look at the impact of technological change on the substitutability and complementarity between factors of production, in particular weapons and soldiers. We assume two kinds of capital: horses and weaponry. Horses in this model are used for fighting, for instance for charging at the enemy on horseback armed with a lance or other weapon suitable for use on horseback. Weapons consist of any weaponry used in the time period of analysis ranging from the lances and bayonets to tanks and machine guns.

\footnotetext{
${ }^{1}$ In comparison to only $75 \%$ who indicated that they could swim.
} 
We assume two kinds of labor: tall men and average/regular height men. We allow for a growth rate in the labor stock, we also allow for growth in the efficiency of labor. This may come from technological change that is labor augmenting or simply from improvements through experience.

Together, capital and labor in the military produce victories. We assume that the production function is Cobb-Douglas over horses and that it is CES over the three other inputs: weapons, tall men, average men. As with Krusell et al. there are three ways of nesting weapons, tall and average soldiers. The choice of which to use depends on our assumptions of the elasticity of substitution between average men, tall men and weapons. Our argument is that if technological change is average height augmenting then it drives a shift in demand from predominantly tall men to all heights. We therefore choose a nesting that allows no impact of changes in the weapons stock on the preference for height. ${ }^{2}$

Let

$V\left(k_{h t}, k_{w t}, l_{t t}, l_{r t}\right)=k_{h t}^{\alpha}\left[\mu k_{w t}^{\sigma}+(1-\mu)\left(\lambda l_{r t}^{\rho}+(1-\lambda) l_{t t}^{\rho}\right)^{\sigma / \rho}\right]^{(1-\alpha) / \sigma}$

Where $V$ is victories in time $t, k_{h t}$ is horses in time $t, k_{w t}$ is weapons in time $t, l_{t t}$ is tall soldiers in time $t, l_{r t}$ is average height soldiers in time $t, \mu$ and $\lambda$ are parameters that govern income shares. $\sigma$ and $\rho(\sigma, \rho<1)$ govern the elasticity of substitution between tall soldiers, weapons and regular height soldiers. The elasticity of substitution between weapons (or tall heights) and regular soldiers is $1 /(1-\sigma)$ and the elasticity of substitution between weapons and tall soldiers is $1 /(1$ $\rho) . \alpha$ is a Cobb-Douglas parameter for constant returns to scale for horses and the other inputs. If either $\sigma$ or $\rho$ is zero, the resulting production function is Cobb-Douglas.

As with Krusell et al. each type of labor input is measured in efficiency units: each labor type is a product of the raw number of soldier hours and an efficiency index: $l_{r t}=\psi_{r t} h_{r t}$ and $l_{t t}=\psi_{t t} h_{t t}$, where $h_{i t}$ is the number of hours soldiered and $\psi_{i t}$ is the quality per hour of type i at date t. $\psi_{\text {it }}$ in our case will denote height-specific technology.

First order conditions:

Tall soldiers:

$$
\begin{aligned}
& \frac{d V}{d h_{t t}}=k_{h t}^{\alpha} \frac{(1-\alpha)}{\sigma}\left[\mu k_{w t}^{\sigma}+(1-\mu)\left(\lambda l_{r t}^{\rho}+(1-\lambda) l_{t t}^{\rho}\right)^{\sigma / \rho}\right]^{(1-\alpha-\sigma) / \sigma} \frac{\sigma}{\rho}(1-\mu)\left(\lambda l_{r t}^{\rho}+\right. \\
& \left.(1-\lambda) l_{t t}^{\rho}\right)^{\sigma-\rho} \rho \rho(1-\lambda) l_{t t}^{\rho-1} \psi_{t t}
\end{aligned}
$$

Regular soldiers:

$$
\begin{aligned}
& \frac{d V}{d h_{r t}}=k_{h t}^{\alpha} \frac{(1-\alpha)}{\sigma}\left[\mu k_{w t}^{\sigma}+(1-\mu)\left(\lambda l_{r t}^{\rho}+(1-\lambda) l_{t t}^{\rho}\right)^{\sigma / \rho}\right]^{(1-\alpha-\sigma) / \sigma} \frac{\sigma}{\rho}(1-\mu)\left(\lambda l_{r t}^{\rho}+\right. \\
& \left.(1-\lambda) l_{t t}^{\rho}\right)^{\sigma-\rho} \rho \rho \lambda l_{r t}^{\rho-1} \psi_{r t}
\end{aligned}
$$

\section{Weapons:}

\footnotetext{
${ }^{2}$ Both nesting strategies yield the same result for average height augmenting technological change. They also allow for an impact of increases in the weapons stock (whether lances or tanks) on the demand for tall and average height soldiers which might also explain a shift in demand to average height soldiers.
} 
$\frac{d V}{d k_{w t}}=k_{h t}^{\alpha} \frac{(1-\alpha)}{\sigma}\left[\mu k_{w t}^{\sigma}+(1-\mu)\left(\lambda l_{r t}^{\rho}+(1-\lambda) l_{t t}^{\rho}\right)^{\sigma / \rho}\right]^{(1-\alpha-\sigma) / \sigma} \mu \sigma k_{w t}^{\sigma-1}$

Although the wage paid to soldiers is not necessarily determined by their marginal product we denote the ratio of the two marginal products of the two types of soldiers as the height premium to demonstrate what happens to the marginal product of height with changes in technology. The idea is that as the marginal product of average height soldiers increases relative to tall soldiers the demand for average height soldiers will increase.

We denote height premium by $\pi$ and divide (2) by (3):

$$
\begin{gathered}
\pi_{t}=\frac{1-\lambda}{\lambda} \frac{l_{t t}^{\rho-1} \psi_{t t}}{l_{r t}^{\rho-1} \psi_{r t}} \\
\pi_{t}=\frac{1-\lambda}{\lambda}\left(\frac{h_{r t}}{h_{t t}}\right)^{1-\rho}\left(\frac{\psi_{t t}}{\psi_{r t}}\right)^{\rho}
\end{gathered}
$$

Log-linearising and removing constants:

$$
\ln \pi_{t}=(1-\rho) \ln \left(\frac{h_{r t}}{h_{t t}}\right)+\rho \ln \left(\frac{\psi_{t t}}{\psi_{r t}}\right)
$$

In this specification, changes in the height premium and hence the marginal products take place through the hours soldiered and changes to the efficiency of soldiering. In particular, the height premium decreases if the efficiency of regular height soldiers increases and $\rho>0$. How might regular height soldiers become more efficient? The weapons technology could develop in such a way that it augments the productivity of all heights not just the tallest and hence strongest. For example, advances in artillery might reduce the requirements for strength or advances in the use of chemical weapons need not require strength. We argue that these and other weaponry and tactical changes described above would indeed have caused a substitution away from tall soldiers.

WWI was of course a much larger war than the South Africa war for a number of reasons. The sheer size of the war forced the army to enlist shorter soldiers as it tried to meet its demand for manpower. ${ }^{3}$ Thus the impact of scale reinforced the effect of changing technology on the demand for shorter soldiers. Of course the two effects were not independent of each other. The need for a larger army was driven, in part, by technological change that improved the productivity of the not so tall thereby increasing the demand for those very people. In that sense, the scale of WWI is partly dependent on changes in military technology and not only on the large scale political alliances that contributed to the pre-war arms race and then outbreak of conflict.

Evidence of height differential

We compare seven groups that fought in either the Anglo-Boer War or the First World War. We restrict our attention to men who were born in England between 1860 and 1890 in order to minimize the risk that differences in birthplace or cohort might influence our results. We are able

\footnotetext{
${ }^{3}$ An increase in the overall stock of weapons would not affect the height premium in this model, however the demand for both types of labor relative to weapons would increase and we certainly accept that this was one of the drivers of the massive demand for men during WWI. As noted before, an alternative nesting allows for changes in the height premium given an increase in the weapons stock.
} 
to structure the investigation in this way because large number of men from this cohort migrated to Australia, South Africa and Canada. We use the enlistment records of armies raised in Australia, Canada and South Africa for the Anglo-Boer War and WWI, and for WWI only for the British. British Army attestations available to us for the Anglo-Boer do not record their height. These data allow us to ask, in effect, what kinds of men among those born in England 1860-1890 were selected for the two conflicts, independently in the four jurisdictions.

Figure 2 superimposes histograms of height distributions from the two enlistments (all forces combined). The lumpiness arises from a degree of heaping in height reporting, which was given in inches but here is converted to centimetres. Both distributions are near-normal although the Anglo-Boer has a greater shortfall at low heights and of course is shifted to the right. Both wars enlisted men with a wide distribution of heights, although the Anglo-Boer War appears to have made little use of very short men.

Figure 2: Histogram of heights in two wars

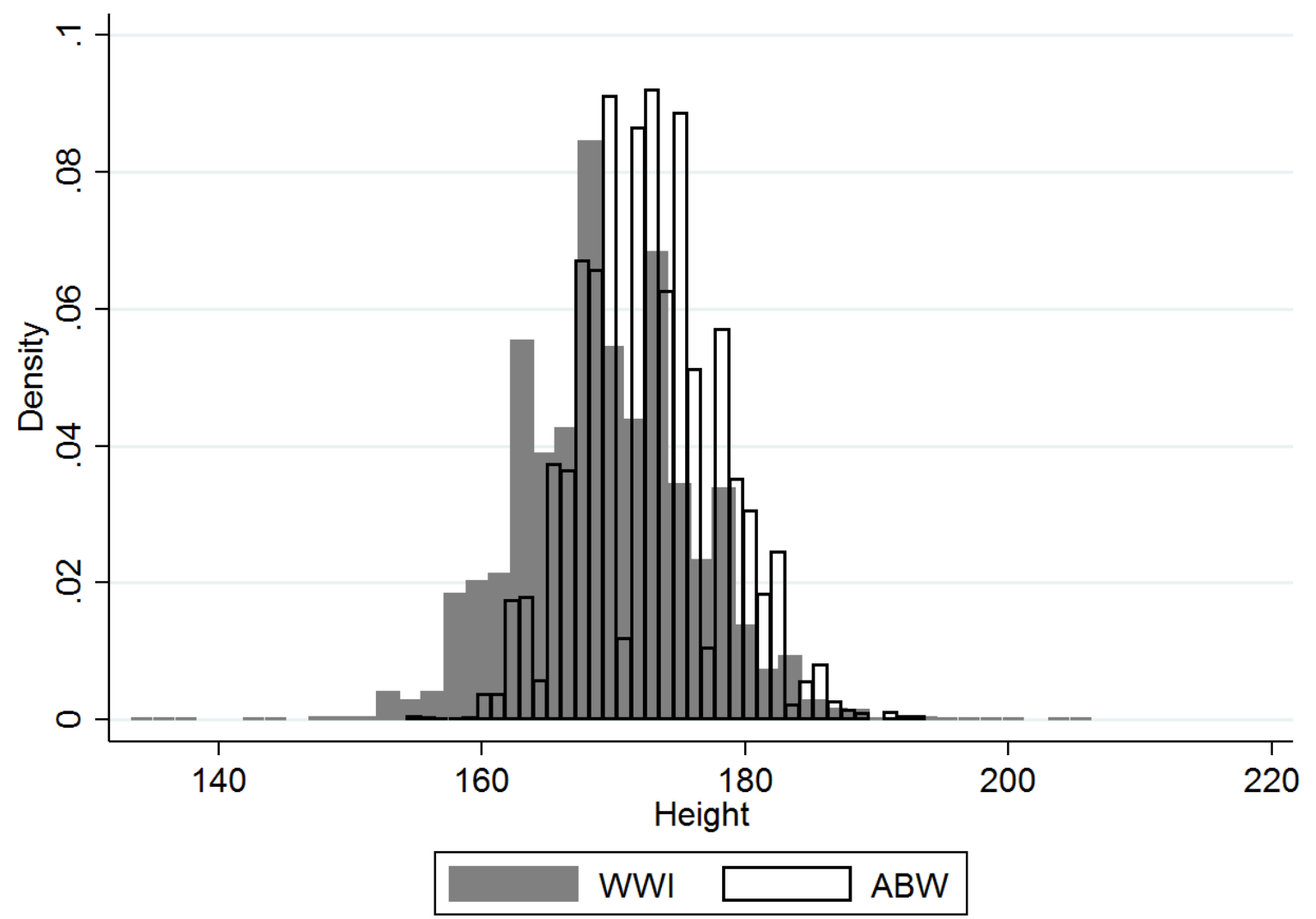

Further descriptive detail is presented in Table 1 and Figure 3. A general height difference between the two wars is clear. English-born recruits who enlisted in the Anglo-Boer War, regardless of enlistment location, on average were taller than soldiers in all of the WWI armies. The smallest mean height in the 1899-1902 conflict (Australian forces) was larger than the largest mean height in WWI (South African forces). English-born Canadian soldiers recruited in the Anglo-Boer War were on average more than $3 \mathrm{cms}$ taller than the English-born recruited more than a decade later in Canada. Presentation of 95\% confidence intervals in Figure 3 reinforces the point. This difference in means support our hypothesis of different selections in the two wars even if we restrict examination to the same cohort and birthplace. Larger standard deviations of height in WWI are also consistent with scope for greater use of short men. 
Table 1: Descriptive statistics of WWI and Anglo-Boer War soldiers born in England, 1860-1885

\begin{tabular}{|c|c|c|c|c|c|c|c|c|}
\hline & Origin & Obs. & $\begin{array}{l}\text { Height } \\
\text { mean }\end{array}$ & $\begin{array}{l}\text { Height } \\
\text { median }\end{array}$ & $\begin{array}{l}\text { Height } \\
\text { std. dev. }\end{array}$ & $\begin{array}{l}\text { Birth } \\
\text { median }\end{array}$ & $\begin{array}{l}\text { Age } \\
\text { median }\end{array}$ & $\begin{array}{l}\text { HISCO } \\
\text { median }\end{array}$ \\
\hline WWI & England & 3594 & 168.0 & 167.6 & 6.42 & 1883 & 32 & 75 \\
\hline WWI & Australia & 4734 & 169.8 & 169.9 & 6.33 & 1889 & 26 & 73 \\
\hline WWI & Canada & 15424 & 169.5 & 169.5 & 6.60 & 1888 & 27 & 71 \\
\hline WWI & South Africa & 1356 & 171.1 & 170.5 & 6.29 & 1882 & 34 & 58 \\
\hline ABW & South Africa & 4387 & 172.9 & 172.7 & 5.25 & 1878 & 23 & 62 \\
\hline$A B W$ & Australia & 375 & 171.6 & 171.5 & 5.73 & 1877 & 25 & 63 \\
\hline ABW & Canada & 1063 & 172.6 & 172.1 & 5.41 & 1876 & 25 & 62 \\
\hline Total & & 30933 & 170.1 & 170.2 & 6.46 & 1884 & 27 & 62 \\
\hline
\end{tabular}

Figure 3: Mean height with 95\% confidence intervals for the seven enlistments

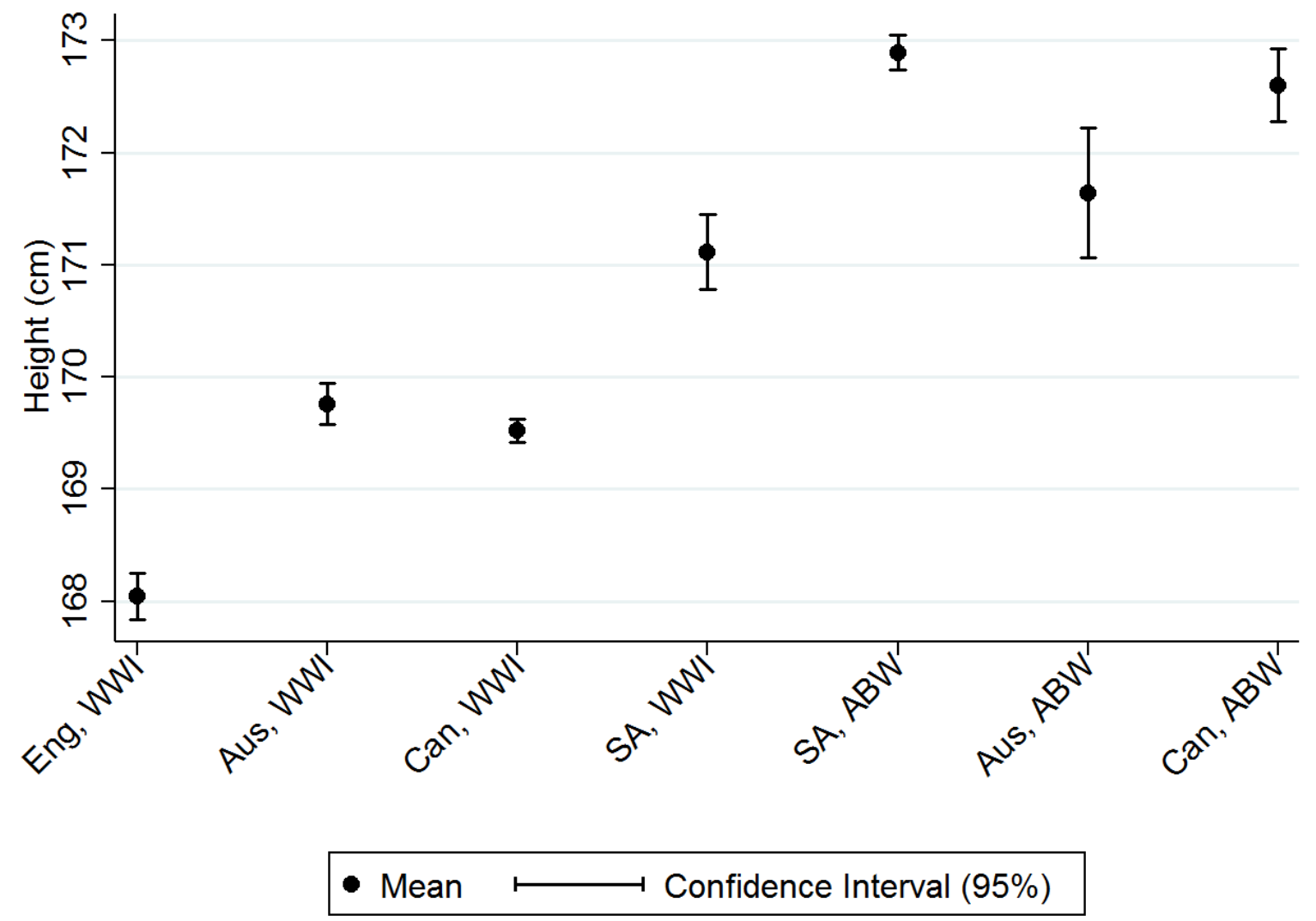

Table 1 also gives the median year-of-birth, the average age and the mode occupation type. There are few notable differences, but it is useful to note the modal occupation for those recruited to the Anglo-Boer War is farmer, while for WWI it is unskilled labourer. This and other compositional differences suggest the importance of a multivariate adjustment for the effect of observable characteristics. We do not and by definition cannot know of any unobservable differences across enlistments, but the identification of occupation, religion and birth year at least allows us to test if the difference between wars survives adjustment for the marginal effect of several important personal characteristics.

We use a simple multivariate analysis to explore further reasons for the difference between wars. To do this, we run the following model across the pooled sample: 


$$
\text { Height }=\beta_{0}+\beta_{1} \text { War }+\beta_{2} \text { Country }+\beta_{3} \text { BirthYear }+\beta_{4} \text { Hisco }+\beta_{5} \text { Religion }+\varepsilon
$$

Our variable of interest is War, which equals one for the Anglo-Boer War and zero for WWI. There is no reason to suspect, a priori, that controlling for the observable characteristics of individuals - country of enlistment, birth year, occupation and religion - would undermine statistical significance on the coefficient for the War dummy. However, if such a significant coefficient is found, we hypothesize, it could suggest a different recruitment policy which we suggest might be related to technology.

In Table 2 we report six different ways of identifying factors that are associated with individual stature and potentially may explain the difference between wars. We employ an ordinary least squares in the first four specifications and a truncated regression approach in the last two (Komlos, 2004, A'Hearn, 2004). None of the econometric experiments reported in Table 2 modify the impression given by the descriptive observations above. A large and statistically significant difference between those fighting in the Anglo-Boer War and in the First World War survives the multivariate control for observable characteristics. Regardless of the specification and the estimation technique used, the difference remains larger than $2 \mathrm{~cm}$ (except in Specification 6 where it falls to $1.7 \mathrm{~cm}$ ) and in some specifications rises to $4 \mathrm{~cm}$.

Why do we observe such a height difference between people born in the same country (England) during roughly the same period but recruited to two different wars? Observable characteristics do not seem to explain the difference: we control for birth year, place of enlistment, occupation and religious differences which should capture any selection on observable characteristics. We know, for example, that following British defeats during the initial stages of the Anglo-Boer War, many upper-class Englishmen felt it their duty to enlist to protect the British Empire. Such patriotic fervour would have biased the sample in favour of taller individuals and that is indeed what happened. In 1900, English-born recruits to the SAC are on average $174 \mathrm{~cm}$ tall whereas in 1901 their average was $172.8 \mathrm{~cm}$. Yet because we include occupation and religion, our control variables should remove this influence.

A more serious possible bias is the selection on height itself. Towards the end of WWI, the numbers of qualifying men who could still enlist dwindled. The authorities were thus forced to lower the minimum height requirement so as to recruit more soldiers. We would expect that the relaxation of this requirement would push the average height of recruits down, and indeed, between 1914 and 1917 the average height of soldiers fell from $170.3 \mathrm{~cm}$ in 1914 to $168.7 \mathrm{~cm}$ in 1917 (Appendix Figure A1).

We mitigate these concerns in several ways. First, in the latter specifications we include controls for year-of-birth and year-of enlistment. These should control for any year-specific changes (such as patriotic fervour or a decline in the availability of recruits). We also exclude the outlier years (unreported), with no changes to our results. In the appendix we provide additional robustness checks to show that our main result holds regardless of the point of truncation, the minimum age of recruits or the year-of-enlistment in WWI. 
Table 2: Regression results

\begin{tabular}{|c|c|c|c|c|c|c|}
\hline & Spec (1) & Spec (2) & Spec (3) & Spec (4) & Spec (5) & Spec (6) \\
\hline ABW & $\begin{array}{r}3.588^{* * *} \\
(27.62)\end{array}$ & $\begin{array}{r}2.517^{* * *} \\
(15.81)\end{array}$ & $\begin{array}{r}2.131^{* * *} \\
(12.80)\end{array}$ & $\begin{array}{r}4.015^{* * *} \\
(8.97)\end{array}$ & $\begin{array}{r}4.006^{* * *} \\
(7.95)\end{array}$ & $\begin{array}{r}1.729 * * \\
(2.76)\end{array}$ \\
\hline Australia & & $\begin{array}{r}1.720^{* * *} \\
(11.58)\end{array}$ & $\begin{array}{r}1.652^{* * *} \\
(9.13)\end{array}$ & $\begin{array}{r}1.922^{* * *} \\
(10.58)\end{array}$ & $\begin{array}{r}1.942^{* * *} \\
(8.40)\end{array}$ & $\begin{array}{r}1.280^{* * *} \\
(3.80)\end{array}$ \\
\hline Canada & & $\begin{array}{r}1.776^{* * *} \\
(14.51)\end{array}$ & $\begin{array}{r}1.658^{* * *} \\
(10.29)\end{array}$ & $\begin{array}{r}1.879 * * * \\
(11.60)\end{array}$ & $\begin{array}{r}1.971 * * * \\
(9.43)\end{array}$ & $\begin{array}{r}1.695^{* * *} \\
(5.50)\end{array}$ \\
\hline South Africa & & $\begin{array}{r}2.852^{* * *} \\
(15.96)\end{array}$ & $\begin{array}{r}2.753 * * * \\
(13.22)\end{array}$ & $\begin{array}{r}3.429 * * * \\
(15.69)\end{array}$ & $\begin{array}{r}3.501^{* * *} \\
(13.02)\end{array}$ & $\begin{array}{r}2.748^{* * *} \\
(7.31)\end{array}$ \\
\hline Hisco 0 & & & $\begin{array}{r}1.075^{* * *} \\
(4.88)\end{array}$ & $\begin{array}{r}1.023^{* * *} \\
(4.66)\end{array}$ & $\begin{array}{r}1.069 * * * \\
(4.29)\end{array}$ & $\begin{array}{r}0.573 \\
(1.88)\end{array}$ \\
\hline Hisco 1 & & & $\begin{array}{r}0.655^{* *} \\
(2.61)\end{array}$ & $\begin{array}{r}0.685^{* *} \\
(2.74)\end{array}$ & $\begin{array}{l}0.458 \\
(1.59)\end{array}$ & $\begin{array}{l}-0.262 \\
(-0.71)\end{array}$ \\
\hline Hisco 2 & & & $\begin{array}{r}0.774 * \\
(2.31)\end{array}$ & $\begin{array}{r}0.903^{* *} \\
(2.70)\end{array}$ & $\begin{array}{r}0.797^{*} \\
(2.06)\end{array}$ & $\begin{array}{l}0.154 \\
(0.31)\end{array}$ \\
\hline Hisco 3 & & & $\begin{array}{r}0.421^{*} \\
(2.53)\end{array}$ & $\begin{array}{r}0.371^{*} \\
(2.24)\end{array}$ & $\begin{array}{l}0.344 \\
(1.78)\end{array}$ & $\begin{array}{l}-0.159 \\
(-0.65)\end{array}$ \\
\hline Hisco 4 & & & $\begin{array}{r}0.756^{* * *} \\
\text { (3.49) }\end{array}$ & $\begin{array}{r}0.727^{* * *} \\
(3.37)\end{array}$ & $\begin{array}{r}0.698^{* *} \\
(2.81)\end{array}$ & $\begin{array}{l}0.043 \\
(0.14)\end{array}$ \\
\hline Hisco 5 & & & $\begin{array}{r}-0.288 \\
(-1.64)\end{array}$ & $\begin{array}{r}-0.304 \\
(-1.73)\end{array}$ & $\begin{array}{r}-0.342 \\
(-1.66)\end{array}$ & $\begin{array}{r}-0.590^{*} \\
(-2.22)\end{array}$ \\
\hline Hisco 7 & & & $\begin{array}{r}-1.409 * * * \\
(-8.20)\end{array}$ & $\begin{array}{r}-1.399 * * * \\
(-8.17)\end{array}$ & $\begin{array}{r}-1.540 * * * \\
(-7.41)\end{array}$ & $\begin{array}{r}-1.432 * * * \\
(-5.07)\end{array}$ \\
\hline Hisco 8 & & & $\begin{array}{r}-1.109 * * * \\
(-7.01)\end{array}$ & $\begin{array}{r}-1.127^{* * *} \\
(-7.15)\end{array}$ & $\begin{array}{r}-1.302 * * * \\
(-6.88)\end{array}$ & $\begin{array}{r}-1.636^{* * *} \\
(-6.41)\end{array}$ \\
\hline Hisco 9 & & & $\begin{array}{r}-1.240 * * * \\
(-9.47)\end{array}$ & $\begin{array}{r}-1.288 * * * \\
(-9.86)\end{array}$ & $\begin{array}{r}-1.522 * * * \\
(-9.75)\end{array}$ & $\begin{array}{r}-1.690 * * * \\
(-8.10)\end{array}$ \\
\hline Other & & & & & & \\
\hline Protestant & & & $\begin{array}{r}-0.618^{* * *} \\
(-5.43)\end{array}$ & $\begin{array}{r}-0.522^{* * *} \\
(-4.59)\end{array}$ & $\begin{array}{r}-0.637^{* * *} \\
(-4.62)\end{array}$ & $\begin{array}{r}-0.668 * * * \\
(-3.55)\end{array}$ \\
\hline Roman & & & & & & \\
\hline Catholic & & & $\begin{array}{r}-0.887 * * * \\
(-4.64)\end{array}$ & $\begin{array}{r}-0.882 * * * \\
(-4.63)\end{array}$ & $\begin{array}{r}-1.132 * * * \\
(-4.80)\end{array}$ & $\begin{array}{l}-0.610 \\
(-1.86)\end{array}$ \\
\hline Jewish & & & $\begin{array}{r}-4.955^{* * *} \\
(-7.53)\end{array}$ & $\begin{array}{r}-4.831^{* * *} \\
(-7.37)\end{array}$ & $\begin{array}{r}-5.027^{* * *} \\
(-5.14)\end{array}$ & $\begin{array}{r}-4.696^{* *} \\
(-2.87)\end{array}$ \\
\hline Non-religious & & & $\begin{array}{l}0.678 \\
(1.17)\end{array}$ & $\begin{array}{l}0.628 \\
(1.09)\end{array}$ & $\begin{array}{l}0.631 \\
(0.94)\end{array}$ & $\begin{array}{l}0.929 \\
(1.07)\end{array}$ \\
\hline Yr birth & YES & YES & YES & YES & YES & YES \\
\hline Yr enlist & NO & NO & NO & YES & YES & YES \\
\hline Constant & $\begin{array}{r}169.581^{* * *} \\
(482.09)\end{array}$ & $\begin{array}{r}168.151^{* * *} \\
(464.74)\end{array}$ & $\begin{array}{r}168.886^{* * *} \\
(417.77)\end{array}$ & $\begin{array}{r}167.944^{* * *} \\
(387.15)\end{array}$ & $\begin{array}{r}168.040^{* * *} \\
(325.18)\end{array}$ & $\begin{array}{r}171.069^{* * *} \\
(251.67)\end{array}$ \\
\hline Sigma constant & & & & & $\begin{array}{r}6.404^{* * *} \\
(148.92) \\
\end{array}$ & $\begin{array}{r}5.749 * * * \\
(85.13) \\
\end{array}$ \\
\hline R-squared & 0.041 & 0.053 & 0.066 & 0.076 & & \\
\hline $\mathrm{N}$ & 24761 & 24761 & 22505 & 22505 & 21562 & 14074 \\
\hline
\end{tabular}

Notes: WWI, English recruits, farmers (HISCO 6) and Church-of-England are the control groups. 


\section{Conclusion}

It seems clear that these two enlistments represent different selections of men born in England between 1860 and 1885. We have argued on conceptual grounds that changes in military technology might plausibly alter the demand for different kinds of soldiers in a way that reduced average stature. And we demonstrate that military technology changed in exactly this way from the Anglo-Boer War, which was largely a conflict between horse-mounted units, to the increasingly mechanized armies of World War One. Thus, the evolution of military stature is consistent with our simple models of labour and technology. This observation is based on an examination of a single cohort of English-born who enlisted in four distinct locations and is robust to statistical controls for a range of potentially intervening influences, decisions about truncation point and the inclusion of outliers.

There may be other selection differences between Anglo-Boer War and WWI. It is possible, for example, that differences in the state of the business cycle between 1899 and 1913 account for some of the decline in military height. This effect is unlikely to be important for the enlistments in Canada, since the 1899-1902 forces were raised at a time of booming labour demand in contrast to 1914-1918 which coincided with a significant downturn beginning in the second half of 1913 (Safarian 1970: 26; Urquhart 1993). Accordingly, for Canada at least, business cycle influences on the labour market should have increased rather than decreased the stature of military recruits from one war to the next. The opposite might be true of Australia although the picture is unclear as most of that literature considers long term trends rather than the business cycle (Haig 2001; McLean and Pincus 1983). More broadly, differences in business cycle trajectory in our four recruiting locations makes it unlikely that selection of the kind identified by Bodenhorn, Guinanne and Mroz (2017) contributed much, if at all to the observed stature decline.

Neither is it clear that adverse health and nutrition forces of early industrialization can account for the decline, since we compare soldiers in the two wars born in the same cohort. Admittedly, WWI soldiers were born disproportionately later in the cohort than the Anglo-Boer War soldiers. And yet, all of our models specify year of birth as an explanatory variable. This effectively removes from consideration any downward pressure on stature due to 'industrial growth puzzle' influences.

We conclude that the apparent decline in stature from one enlistment to the other reflects a shift in the technology of war and derived military demand for labour, as outlined above. The greater scale of WWI also may have increased demand for shorter soldiers, although as noted above the scale effect was not independent of changing technology. The scale and technology effects reinforced each other. Together, they imply that a comparison of the two enlistments should not be used as evidence of declining stature in the wider population from which soldiers were selected. Rather, we are seeing the effects of a selection arising from labour demand that has not previously be recognized in the selection bias literature. 


\section{REFERENCES}

A'Hearn, B. 2004. A Restricted Maximum Likelihood Estimator for Truncated Height Samples. Economics and Human Biology, 2, 5-20.

Badsey, S. 2007. The Boer War (1899-1902) and British Cavalry Doctrine: A Re-Evaluation. Journal of Military History, 71, 75-97.

Bailey, R., Hatton, T. \& Inwood, K. 2016. Health, Height and the Household at the Turn of the $20^{\text {th }}$ Century. Economic History Review, 2016, 35-53.

Bodenhorn, H., Guinanne, T. \& Mroz, T. 2017. "Sample-Selection Biases and the Industrialization Puzzle." Journal of Economic History 77:1, pp. 171-207.

Boot, M. 2006. War Made New: Technology, Warfare and the course of history, 1500 to today, New York, Gotham Books.

Castaldi, C., Fontana, R. \& Nuvolari, A. 2009. 'Chariots of fire': the evolution of tank technology, 1915-1945. Journal of Evolutionary Economics, 19, 545-566.

Citino, R. 2002. Decisive Victory: From Stalemate to Blitzkrieg in Europe, 1899-1940, Lawrence, University of Kansas Press.

Clarke, N., Cranfield, J. \& Inwood, K. 2014. Fighting Fit? Diet, Disease, and Disability in the Canadian Expeditionary Force, 1914-18. War and Society, 33, 80-97.

Cranfield, J. \& Inwood, K. 2015. A Tale of Two Armies: Australian and Canadian Soldiers in World War One. Australian Economic History Review, 55, 212-233.

Fourie, J., Grundlingh, A. \& Mariotti, M. 2017. 'Poor South Africa! Will no nice English people ever come out here?' - The South African Constabulary of the Anglo-Boer War. Journal of Imperial and Commonwealth History, 45, 580-606.

Grundlingh, A. 1991. 'Protectors and friends of the people'? The South African Constabulary in the Transvaal and Orange River Colony, 1900-1908. In: ANDERSON, D. M. \& KILLINGRAY, D. (eds.) Policing the empire: Government, authority and control, 1830-1940. Manchester: Manchester University Press.

Haig, B. 2001. New Estimates of Australian GDP: 1861-1948/49. Australian Economic History Review, 41, 1-34.

Haines, M. R. 2004. Growing Incomes, Shrinking People: Can Economic Development Be Hazardous to Your Health? Social Science History, 28, 249-270.

Inwood, K. \& Masakure, O. 2013. Poverty and Physical Well-being among the Coloured Population in South Africa. Economic History of Developing Regions, 28, 56-82.

Komlos, J. 1998. Shrinking in a growing economy? The mystery of physical stature during the industrial revolution. Journal of Economic History, 58, 779-802.

Komlos, J. 2004. How to (and How Not to) Analyze Deficient Height Samples: an Introduction. Historical Methods: A Journal of Quantitative and Interdisciplinary History, 37, 160-173. 
Liaropoulos, A. N. 2006. Revolutions in Warfare: Theoretical Paradigms and Historical Evidence: The Napoleonic and First World War Revolutions in Military Affairs. Journal of Military History, 70, 363-384.

McLean, I. W., and Pincus, J. 1983. Did Australian Living Standards Stagnate between 1890 and 1940? Journal of Economic History, 43, 193-202.

Phillips, G. 2007. Scapegoat Arm: Twentieth-Century Cavalry in Anglophone Historiography. Journal of Military History, 71, 37-74.

Raudzens, G. 1990. War-Winning Weapons: The Measurement of Technological Determinism in Military History. Journal of Military History, 54, 403-434.

Safarian, A.E. 1970. The Canadian economy in the Great Depression. Toronto, McClelland and Stewart.

Steckel, R. H. 1995. Stature and the Standard of Living. Journal of Economic Literature, 33, 19031940.

Swart, S. 2010. Horses in the South African War, c. 1899-1902. Society and Animals, 18, 348-366.

Urquhart. M.C. 1993. Gross national product, Canada 1879-1927, Montreal and Kingston, McGillQueens University Press.

Van Leeuwen, M., Maas, I. \& Miles, A. 2004. Creating a Historical International Standard Classification of Occupations An Exercise in Multinational Interdisciplinary Cooperation. Historical Methods: A Journal of Quantitative and Interdisciplinary History, 37, 186-197.

Zimran, A. 2018. Intuition to Recognize and Address Sample-Selection Bias in Historical Sources With Illustrations from the Historical Heights Literature. mimeo 


\section{APPENDIX}

Figure A1: Height by year-of-enlistment

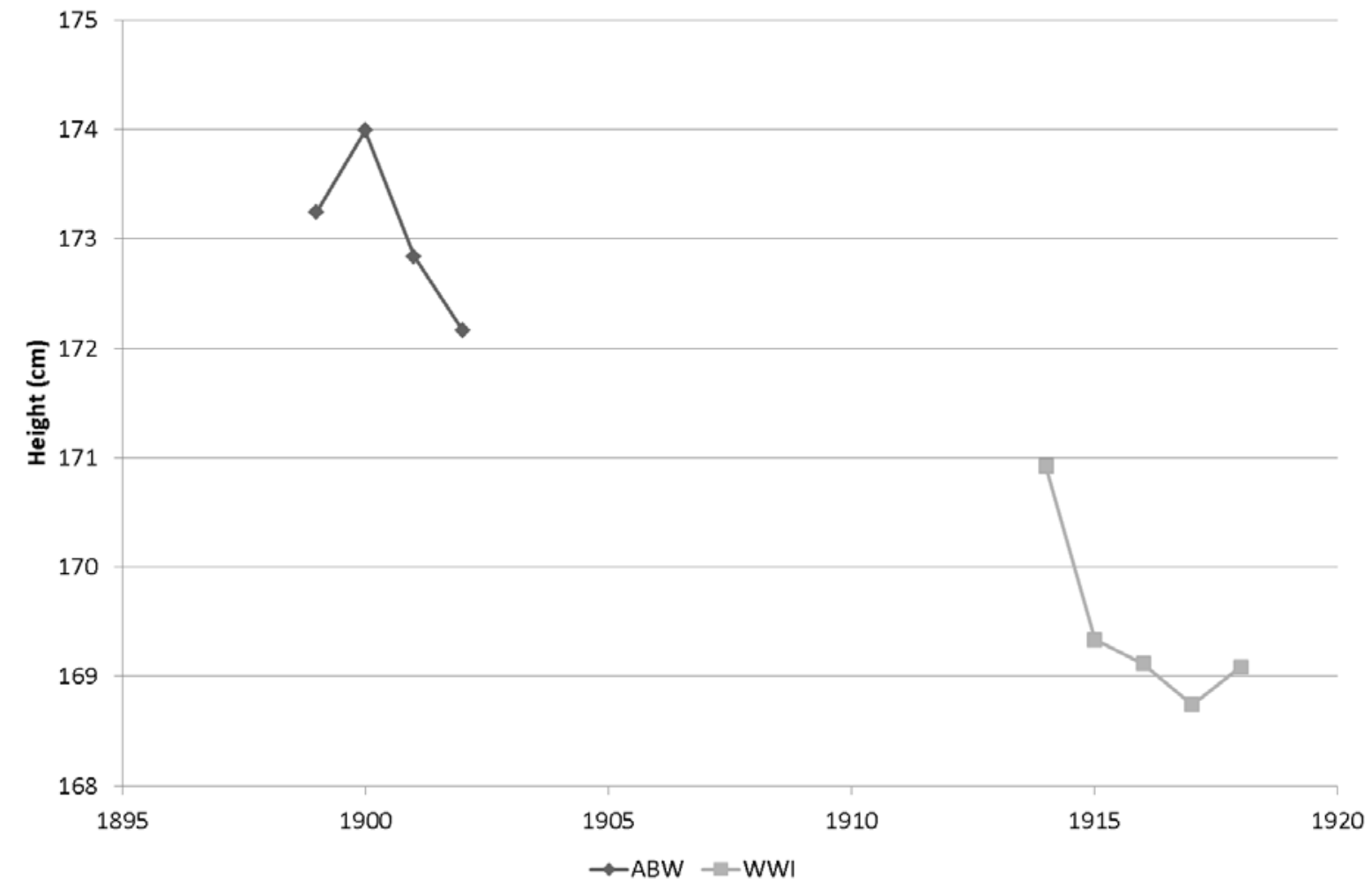

We run several robustness checks. The first is to identify whether the point of truncation matter for our results. We rerun specification six above with three different truncation points: five foot zero $(152.4 \mathrm{~cm})$, five foot three $(160.02 \mathrm{~cm}$, our standard specification) and five foot six $(167.64$ $\mathrm{cm})$. Figure A2 shows the additional height advantage of recruits in World War I. While there are nearly no difference between the first two truncation points, the size of the coefficient falls significantly when the third truncation point is used. Nevertheless, even though the size falls, WWI recruits' heights are still significantly shorter than those of recruits to the Anglo-Boer War. 
Figure A2: Coefficient on WWI dummy with different truncation points

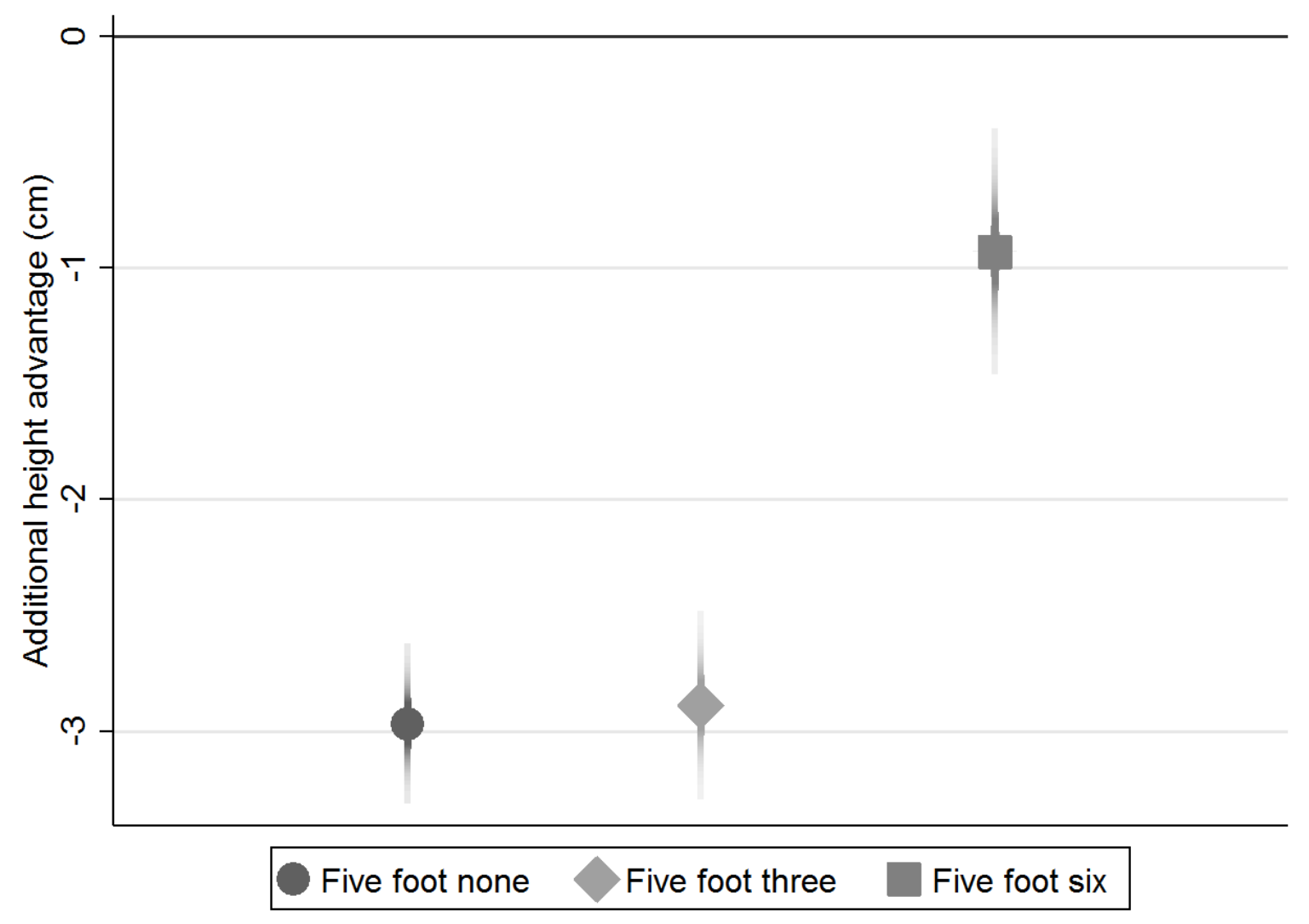

We also check whether the age of recruitment affects our results. We again run specification six across three different classifications for the minimum height. One regression includes soldiers 20 years old and older, another one includes soldiers 22 and older (the standard specification) and the third regression includes only soldiers 24 years or older. Figure A3 shows that as the minimum age increases, the difference between the ABW and the WWI recruit heights increase. 
Figure A3: Coefficient on WWI dummy with different age minimums

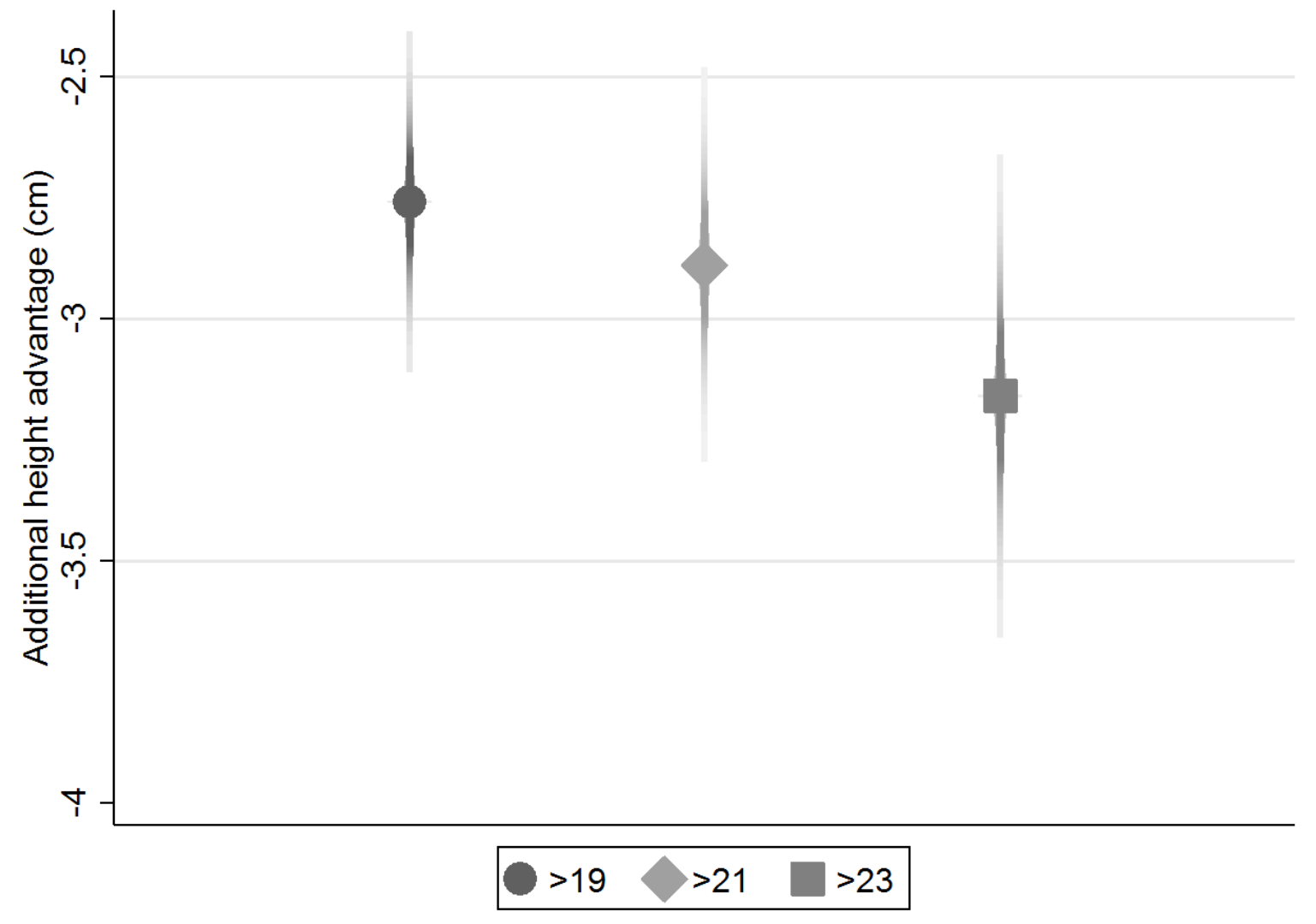

Finally we check whether our results are dependent on recruitment during the last years of WWI. Figure A4 shows changes to the WWI dummy as the year-of-enlistment is increased from 1914 only to encompass the entire First World War (1914-1918). It clearly shows that even if only 1914 is included as year-of-enlistment, recruits are still significantly shorter than recruits during the Anglo-Boer War. The gap increases when recruits in 1915 are added and then stabilises. 
Figure A4: Coefficient on WWI dummy with different year-of-enlistment dates

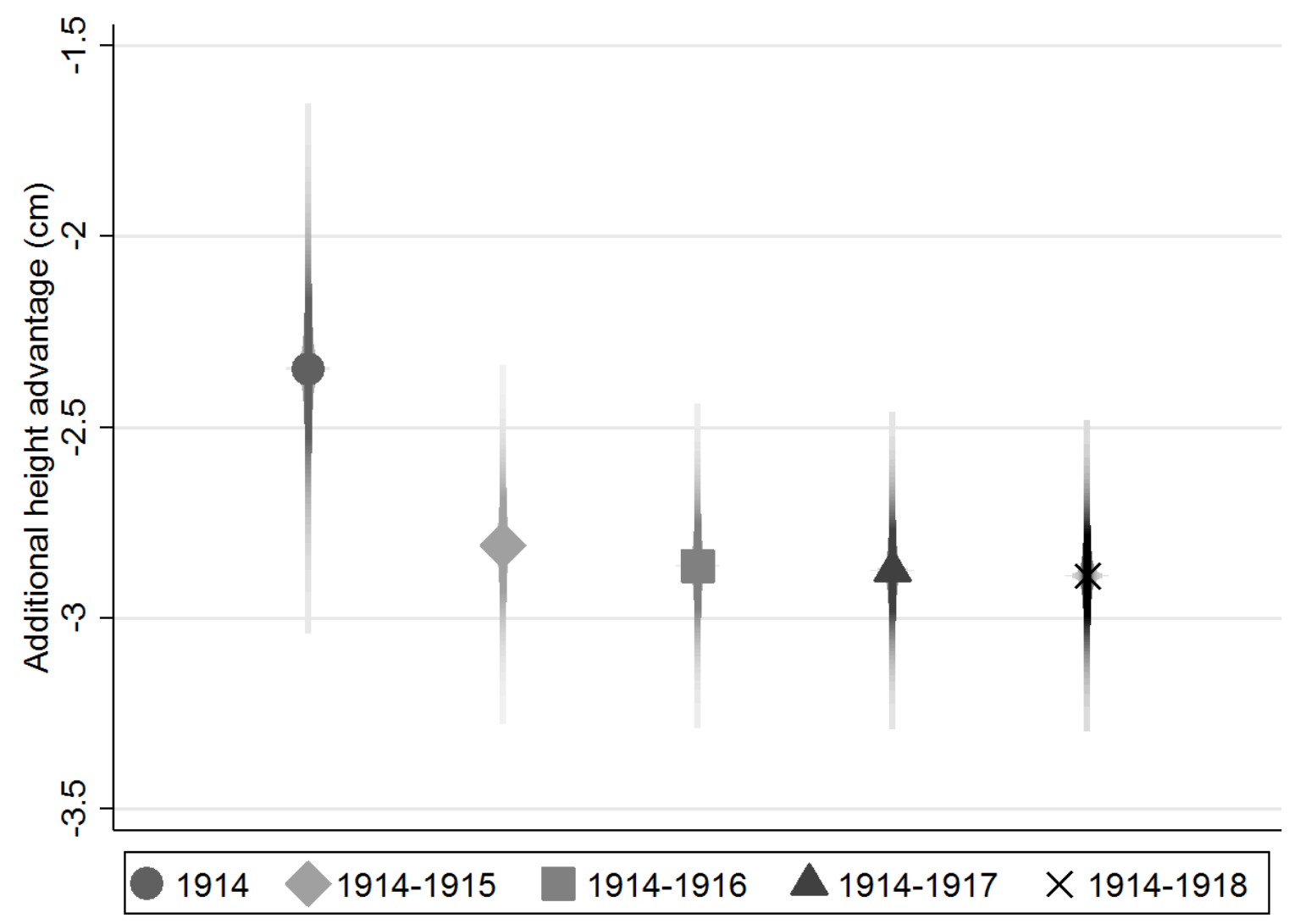

